\title{
LOOP-MEDIATED ISOTHERMAL AMPLIFICATION AS A GOOD TOOL TO STUDY CHANGING Leptosphaeria POPULATIONS IN OILSEED RAPE PLANTS AND AIR SAMPLES
}

\author{
Małgorzata Jędryczka ${ }^{1}$, Adam Burzyński², Andrzej Brachaczek³ ${ }^{3}$ Wojciech Langwiński ${ }^{4}$, \\ Peiling Song ${ }^{5}$, Joanna Kaczmarek ${ }^{1}$
}

\author{
${ }^{1}$ Institute of Plant Genetics, Polish Academy of Sciences, Strzeszyńska 34, 60-479 Poznań, Poland \\ ${ }^{2}$ Novazym Polska, Żywokostowa 23, 61-680 Poznań, Poland \\ ${ }^{3}$ DuPont Poland Ltd., Postępu 17b, 02-676 Warsaw, Poland \\ ${ }^{4}$ Poznań University of Life Sciences, Wojska Polskiego 28, 60-637 Poznań, Poland \\ ${ }^{5}$ Inner Mongolia Academy of Agricultural \& Animal Husbandry Sciences \\ 22 Zhaojun Road, Yuquan District, Hohhot, Inner Mongolia 010031, P.R.China \\ e-mail: jkac@igr.poznan.pl
}

Received: 21.06.2013

\section{Abstract}

LAMP is an innovative, simple, rapid, specific and cost-effective nucleic acid amplification method. Due to the use of a special enzyme - GspSSD polymerase, the reaction takes a short time and can be performed at isothermal conditions. The sensitivity and specificity of LAMP technique is significantly higher, than standard PCR techniques, as two or three specific primer pairs are used. The technique is regarded as a useful tool for the detection and identification of plant pathogens. In this work, LAMP was used to study the composition of the population of fungi of the genus Leptosphaeria, causing a damaging disease of oilseed rape, called blackleg or stem canker. The detection concerned DNA present in fungal spores contained in air samples obtained using Hirst-type volumetric trap, in Pomerania (north Poland) in 2010. The results achieved using the LAMP technique were similar to these obtained with previously used, highly specific method of Real-time PCR. Conducting LAMP reaction was much easier and less time-and cost-consuming, due to a simplified method of DNA isolation of pathogens from plant tissues. Then, the LAMP technique was used to assess the composition of the population of Leptosphaeria spp. in plants of oilseed rape collected from the field in the Opole region (south-western part of Poland) in 2013. In contrast to studies conducted in 2002-2003, the analysis of leaf symptoms showed a higher proportion of L. maculans compared to L. biglobosa, what reflects changes in the composition of pathogen population of fungi causing blackleg on oilseed rape in this part of Poland.

Key words: blackleg; isothermal DNA amplification; Leptosphaeria maculans; L. biglobosa; phoma leaf spotting, stem canker; oilseed rape, Real-time PCR

\section{INTRODUCTION}

Classical pathogen detection and identification using subcultures of isolates on agar, solid or liquid media, followed by microscope identification is still a core technology used in numerous laboratories worldwide. Such methods provide important information on viability of pathogens and allow to test their susceptibility to different substances and treatments [1]. However, considerable progress in detection of infectious diseases has been observed over the last decade using molecular techniques, based on the detection of nucleic acids [2]. In this case we assume the pathogen is viable and we concentrate on its early and fast detection, which requires simple, but high resolution techniques.

Loop-mediated Isothermal AMPlification (LAMP) is a technique, which allows the amplification of DNA in a single tube [3]. The simplicity of the method makes it an ideal for a low cost alternative to detect DNA of a pathogen in host tissues. Amplification of nucleic acids in isothermal conditions removes the need to perform the reaction in a thermal cycler [4]. In isothermal premixes for LAMP reaction an innovative enzyme GspSSD DNA polymerase is used. This enzyme exhibits strand displacement activity, which enables amplification in isothermal conditions, without the need for denaturation of the DNA template [1]. The enzyme also exhibits an activity of reversetranscriptase, so simultaneous reverse transcription and LAMP amplification are possible in one reaction. 
Detection of the amplification product can be determined using photometry for turbidity, since amplification results in an increase in the quantity of magnesium pyrophosphate produced in solution as a byproduct [5]. An alternative method to measure amplification of the target DNA product is to add SYBR Green and measure fluorescence. The production of large quantities of the amplified product can be easily checked using the naked eye, without the need for expensive equipment. Another possibility to study results of an experiment is the use of manganese loaded calcein. During in vitro DNA synthesis, calcein starts fluorescing during complexation of manganese by pyrophosphate, and the result can be visualized using fluorescent light [1].

The LAMP technique is simple, yet innovative. Rapid and specific detection of certain fragments of nucleic acid is cost-effective [6]. Typical LAMP reactions are performed at a pre-set, unchanged temperature at $60-70^{\circ} \mathrm{C}$ for $15-60$ minutes. The sensitivity and specificity of LAMP is regarded as significantly higher, as compared to standard PCR techniques. In contrast to standard PCR, where one primer pair is used, the method uses two or three primer pairs with 120-170 bp compatibility between primers and template sequences, which achieves high specificity of DNA amplification. The use of loop primers accelerates the reaction [7].

LAMP analysis is a very powerful means for rapid detection of pathogen DNA and the technique has a wide use in identification of genetic diseases of humans, animals, plants and microorganisms. Moreover, as DNA fragments are the object of detection, a time-consuming and laborious culturing of pathogens can be omitted in many cases [4]. Due to the high specificity of the technique, detection may be successful even in case of tiny amounts of the pathogen. These features of LAMP and the special applicability of this innovative technique for detection and identification of pathogens made us try to use the technique for studies of the pathogens responsible for phoma leaf spotting and stem canker, which is an important disease of brassicas, including oilseed rape. The disease is caused by Leptosphaeria maculans and L. biglobosa, two related fungal species, that separately or jointly exist in oilseed rape leaves and stems [8]. In this study we have checked whether this novel technique can discriminate these two Leptosphaeria species in oilseed rape plant tissues and DNA obtained from air samples.

\section{MATERIALS AND METHODS}

\section{Air sampling and DNA extraction from air samples}

Samples were collected in Charbielin (N $50^{\circ} 20^{\prime} 37.2^{\prime \prime} \mathrm{E} 17^{\circ} 25^{\prime} 49.1^{\prime \prime}$, south-west part of Poland) on 15-24 September 2010. The study was done using a seven-day volumetric spore sampler by Burkard Manufacturing (Rickmansworth, UK) operated outdoors, in natural weather conditions. The sampler was surrounded by oilseed rape stubble collected from Charbielin fields with oilseed rape after harvest in July 2010.

The cellophane tapes were cut into sections (48 $\mathrm{mm}$ long), using sterile forceps and scissors. Longwise half of a tape was used for microscopy and the other half of a tape was placed into a $2 \mathrm{ml}$ plastic tube. To each of these tubes, one scoop (approx. $150 \mathrm{mg}$ ) of sterile acid-washed Ballotini beads $(425-600 \mu \mathrm{m}$ diameter) were added followed by CTAB buffer, using a method of $\mathrm{K} \mathrm{a} \mathrm{c} \mathrm{z} \mathrm{m} \mathrm{a} \mathrm{r} \mathrm{e} \mathrm{k} \mathrm{et} \mathrm{al.} \mathrm{[9].} \mathrm{The} \mathrm{samples} \mathrm{were}$ then placed in a FastPrep machine (Savant Instrument, Holbrook, New York, USA) and processed, two times at $6 \mathrm{~ms}^{-1}$ for 40 seconds, with 2 minutes cooling on ice between each cycle. The extraction was done using chloroform : isoamyl alcohol (24:1).

\section{Plant sampling and DNA extraction from infected plants}

Plant samples were collected in Radostowo (N 5359'27.0" E 1843'50.5”, central-north part of Poland) before harvest of oilseed rape in July 2013. Thirty stems with visible symptoms of phoma stem canker were taken from the control plot of oilseed rape cultivar PR46W15 F1 and cut into three sections: root collar, stem base and upper stem. Root collar zone was in between the upper part of the main root and a few millimeters of stem, adjacent to the root; stem base was a part of stem from the ground level up to $5 \mathrm{~cm}$ above and upper stem was a part located at $10 \mathrm{~cm}$ from the bottom of the stem and upwards. About $25 \mathrm{mg}$ of the stem tissue was scraped off the stem, after simplified surface disinfection by wiping the stem with a tissue submerged in $70 \%$ ethanol. DNA extraction was performed in a test tube, using Novabeads Plant DNA Fast Mini Kit with magnetic beads (Novazym, Poznan, Poland) according to the instructions of the manufacturer.

\section{Real-time PCR method of pathogen detection}

For Real-time PCR, a method described by $\mathrm{K}$ a c z m a re k et al. [10] was used. A Real-time PCR assay using SYBR green was optimised for the primers designed by Mahuku et al. [11]. A BioRad CFX96 Touch Real-time PCR machine was used for absolute quantification of L. maculans and L. biglobosa DNA. A standard curve was generated by plotting the crossing cycle $\left(\mathrm{C}_{\mathrm{t}}\right.$ value $)$ number for each sample of a standard series of L. maculans and L. biglobosa DNA from $10 \mathrm{ng}$ to $1 \times 10^{-4} \mathrm{ng}$. Melting curve analysis was done to determine the accuracy of the reaction. 


\section{LAMP method of pathogen detection}

The LAMP assay was carried out in a reaction mixture (final volume $10 \mu \mathrm{l}$ ) containing: $1.6 \mu \mathrm{M}$ each of FIP and BIP primers, $0.2 \mu \mathrm{M}$ each of $\mathrm{F} 3$ and $\mathrm{B} 3$ primers and $0.8 \mu \mathrm{M}$ each of LF and LB primers, $1 \mu \mathrm{l}$ of template DNA (10 ng/ $\mathrm{ul}$ ), Isothermal Mastermix - fluorescent Dye 1x (Optigene, UK) and sterile deionized water. The primers were designed using LAMP primer designing software http://primerexplorer.jp. The mixture was incubated at $64^{\circ} \mathrm{C}$ for 60 min using a thermoblock and then heated at $85^{\circ} \mathrm{C}$ for $2 \mathrm{~min}$ to terminate the reaction. The visual detection was done using Genie II Ultra Rapid Gene Amplificator (Novazym Polska).

\section{RESULTS}

The detection of DNA of L. biglobosa and L. maculans was successful only when the suitable set of primers was used. In all other cases no fluorescence, corresponding to DNA presence, was observed. No fluorescence was observed in case of a negative control (water), but also in the presence of DNA of other fungal species, such as Alternaria alternata, A. brassicae and A. brassicicola as well as Fusarium oxysporum (Fig. 1). Three species belonging to the genus Alternaria, causing dark leaf spot, were studied with special attention, as their symptoms could be mistaken with phoma leaf spotting caused by L. biglobosa.

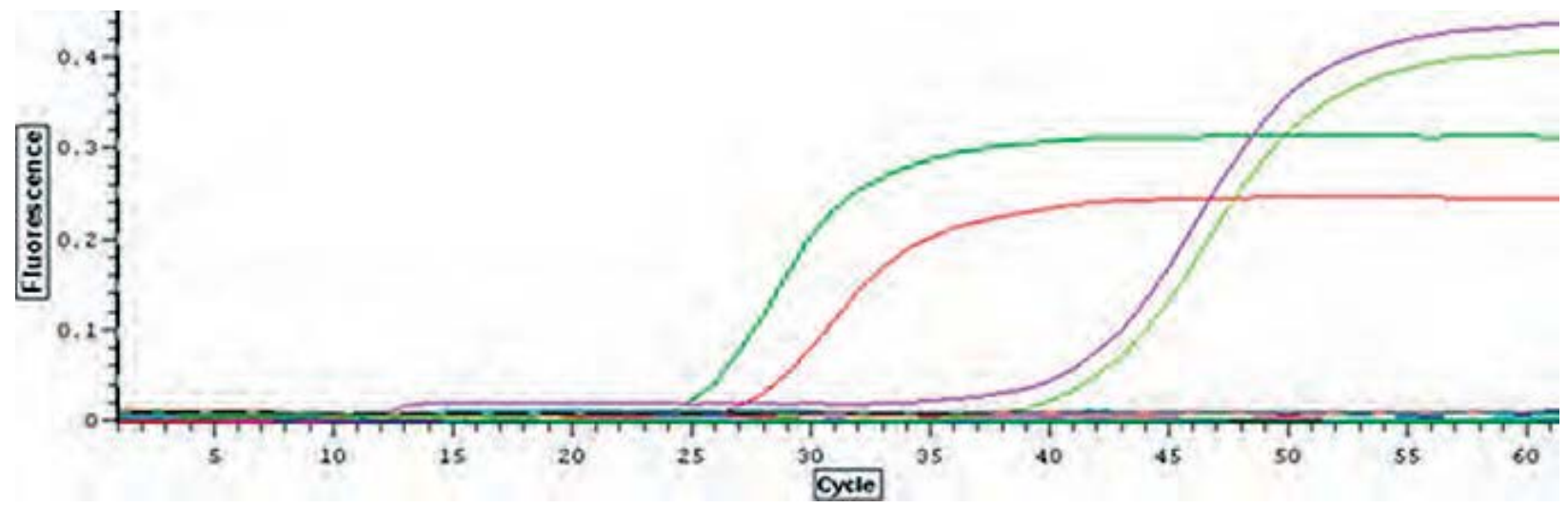

Fig. 1. Fluorescence of amplified DNA obtained using: L. biglobosa standard (bright green line), stem sample infected with L. biglobosa (red line), L. maculans standard (violet line), stem sample infected with L. maculans (pale green), remaining (flat) lines: Alternaria alternata, A. brassicae, A. brassicicola, Fusarium oxysporum, water (negative control).

Results of air sampling obtained using LAMP were similar in comparison to these obtained using Real-time PCR (Fig. 2). On some days (15, 16, 19, 22 and 24 September 2010) only L. biglobosa was detected, whereas on other days $(18,20$ and 23 September 2010) both L. maculans and L. biglobosa were found. The percent of $L$. maculans DNA, corresponding to the number of spores of this species was lower in the study employing Real-time PCR method (16.7\% on average) and 1:1 as shown by LAMP. Two days (17 and 21 September 2010) were free from Leptosphaeria in the air, both studied by Real-time PCR and LAMP. On these days no spores of Leptosphaeria were found by microscopy, whereas on remaining days the ascospores were observed on spore tapes.
Results obtained using pure isolates of L. maculans and L. biglobosa, as well as DNA extracted from these isolates with the CTAB method were identical. In case of isolates obtained from root collars the proportion between L. maculans and L. biglobosa was 7:1 (Fig. 3a). At stem base fragments, obtained from stems cut between ground level up to $5 \mathrm{~cm}$ above, the amount of $L$. maculans was still very high $(72 \%)$ as compared to L. biglobosa (Fig. 3b). Upper parts of stems were mainly inhabited by L. biglobosa, but still some $L$. maculans could be detected (23\%, Fig. 3c). It is probable that the highly sensitive LAMP method allowed to detect very small traces of L. maculans, hardly ever detected using methods of lower resolution. 


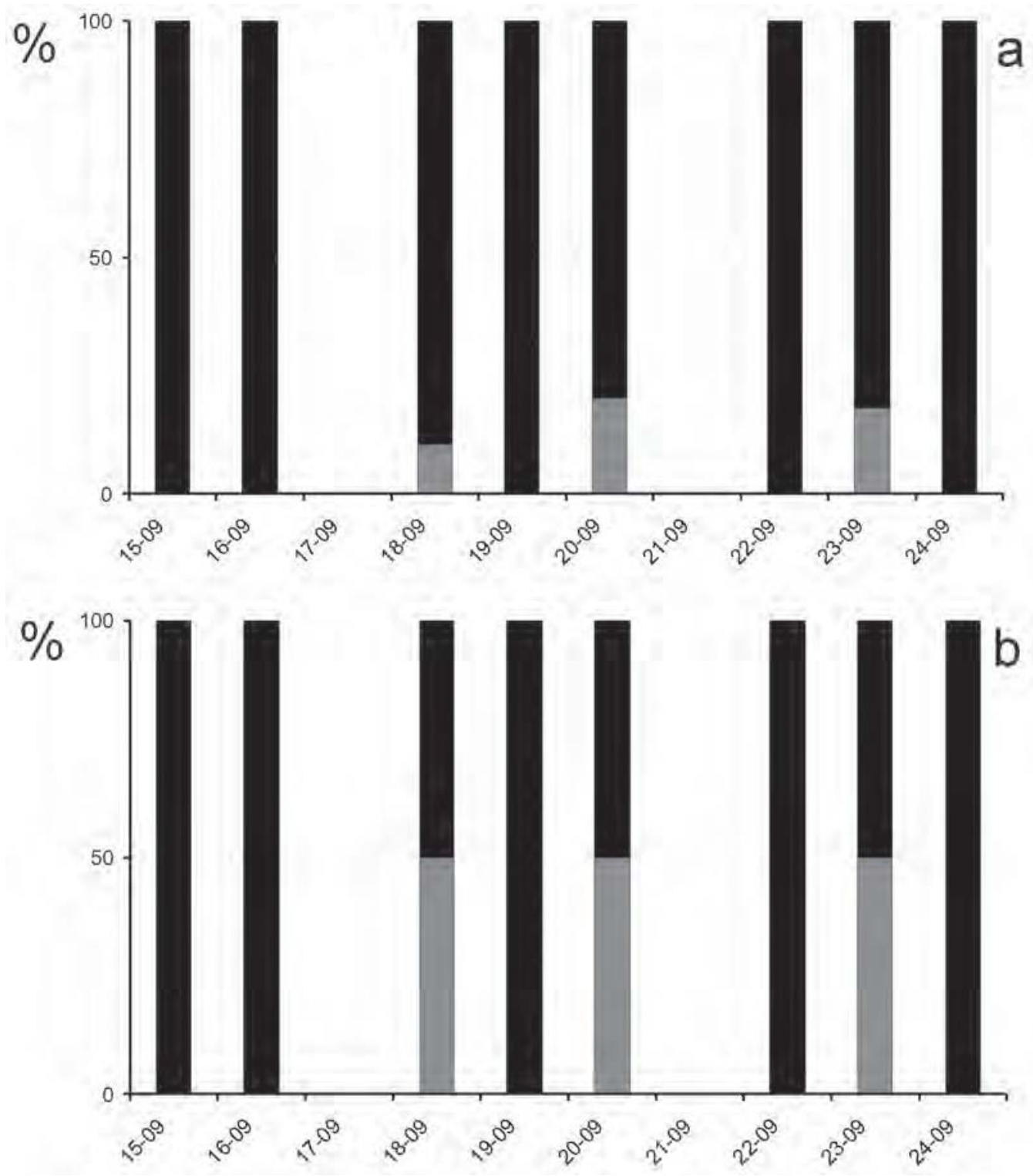

Fig. 2. Molecular identification of Leptosphaeria maculans and L. biglobosa spores in air samples collected in Charbielin (Opole region, south-west Poland) in autumn 2010, based on Real-time PCR (a) and LAMP (b); L. maculans - grey bars, L. biglobosa - black bars.
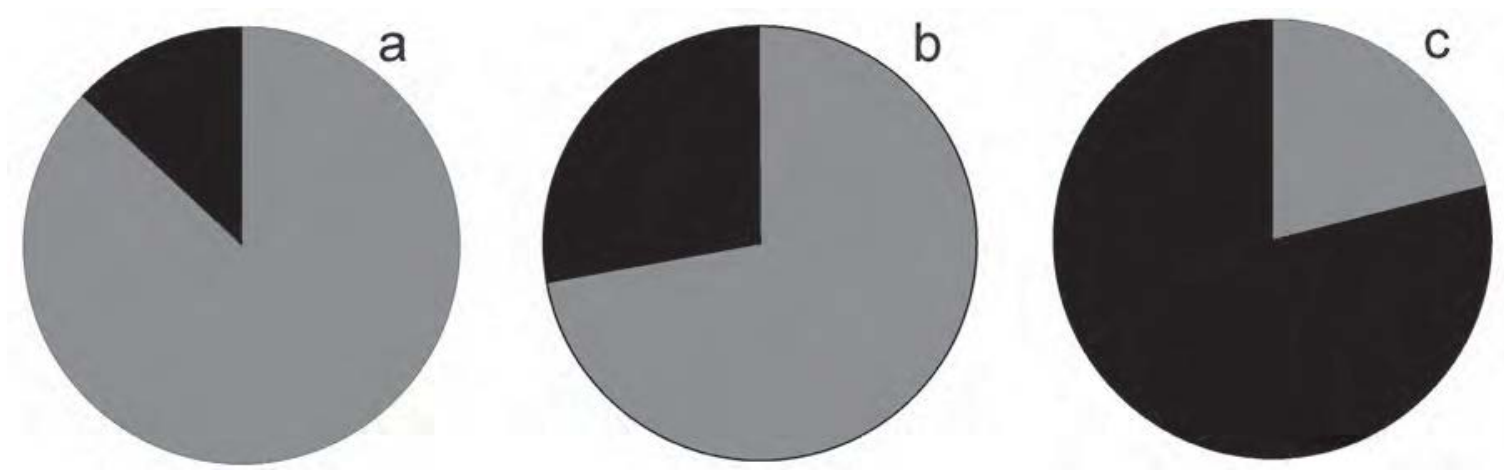

Fig. 3. The composition of Leptosphaeria spp. populations in winter oilseed rape plants in Radostowo (Pomerania, central, north Poland) in summer 2013 on root collar (a), stem base (b) and upper stem part (c); L. maculans - grey area, L. biglobosa black area. 


\section{DISCUSSION}

Reliable, rapid and accurate detection of plant pathogens is essential for the management of plant diseases. In the opinion of Tom lin s on and B o on$\mathrm{h}$ a m [4], methods based on PCR have advantages of sensitivity and specificity that make them valuable tools for pathogen detection. However, the difficulties and high costs of PCR, and especially of the Real-time PCR method make them difficult to apply in more cases than for scientific purposes or commercial tests. It is widely believed that LAMP method has the potential to overcome many of the limitations of PCR-based methods [6,7]. LAMP exhibits less sensitivity to inhibitory substances present in biological samples than PCR [12]. The robustness of LAMP against inhibitors greatly contributes to saving time and cost with respect to sample processing. Experiments can be done in a water bath or heated block, which means that a study can be carried out in simply equipped laboratories or even under field conditions. Such simplification is of great importance for the majority of local testing stations that are not supplied with highly sophisticated and expensive equipment and they do not have a well trained and skilled personnel with molecular expertise [13].

In this study, Loop-mediated Isothermal AMPlification technique was successfully used to describe the population of Leptosphaeria in oilseed rape plants and air samples from southern Poland. By now, pseudothecial maturation and ascospore release of L. maculans and L. biglobosa in this part of Poland was done using traditional techniques based on microscopy [14]. The primers allowed the detection of both species with high specificity. Moreover, the DNA extraction step was easier and more efficient, due to the lack of need to isolate the pathogen from plant tissues. The detection was successful both from newly collected materials and from old leaves and stems of the plant, as well as DNA from spore tapes and seeds (data now shown). The DNA extraction from plants was simplified - a fast 5-step purification method with magnetic particles was enough to extract amounts of DNA suitable for detection. In spite of semi-direct DNA extraction from plant tissues no or low inhibitory effects have been observed, as previously reported by $\mathrm{K}$ a $\mathrm{n}$ e $\mathrm{k} \mathrm{o}$ et al. [12]. In contrast to the studies performed in 2002-2003 [15], the analysis of plant samples collected in the autumn from oilseed rape leaves in West European countries has shown higher amounts of L. biglobosa, whereas the samples from Central Europe more frequently contained L. maculans.

LAMP is patented by Tsugunori Notomi and Tetsu Hase as ,Process for synthesizing nucleic acid“ patent US $6410278 \mathrm{~B} 1$, so it is at present not clear to what extent the method may be used for the detection of pathogens. In Japan, LAMP has been employed in some officially recommended methods for the routine identification and surveillance of pathogens [1]. The method proved its usefulness in rapid detection of infectious bacteria [16], viruses $[17,18]$ as well as for the detection of genetically manipulated plants [19]. It also allows a rapid and direct detection of pathogen variants, such as bacteria resistant to narrow spectrum antibiotics, eg. methicillin [20]. In this study the method proved its high efficiency and good resolution in the detection of oilseed rape pathogens responsible for phoma leaf spotting and stem canker. The method proved its usefulness in discriminating $L$. maculans and $L$. biglobosa - two closely related fungal species that cause stem canker of brassicas.

\section{CONCLUSIONS}

As proved by the study presented here, the method of Loop-mediated Isothermal Amplification (LAMP) has a great potential of use as a novel phytodiagnostic tool for the detection, identification and population studies of oilseed rape pathogens, such as Leptosphaeria maculans and L. biglobosa. The method is much faster and cheaper than Real-time PCR, but it gives a less precise quantification of these pathogens in samples.

The analysis of leaf symptoms performed using a LAMP technique showed a higher proportion of L. maculans compared to L. biglobosa, what reflects changes in the composition of pathogen population of fungi causing blackleg on oilseed rape in the south of Poland.

\section{Acknowledgements}

This work was supported by the National Science Centre in Poland, project N N310 298439. The authors thank to Dr Neal Evans (Uniersity of Hertfordshire, the UK) for his help with language corrections.

\section{Authors' contributions}

Concept of the study: MJ; field experiment and sampling: ABra; fungi identification based on culture morphology: MJ; design of primers: ABur; DNA extraction: PS, WL, JK; LAMP: ABur, WL, JK; analysis of research results: MJ, JK; writing of the manuscript: MJ, JK.

\section{REFERENCES}

1. Mori Y, Notomi T. Loop-mediated isothermal amplification (LAMP): a rapid, accurate, and cost-effective diagnostic method for infectious diseases. J Infect Chemother. 2009; 15: 60-69.

2. Vincell P, Tisserad N. Nucleic acid-based pathogen detection in applied plant pathology. Plant Dis. 2008; 92: 660-669. 
3. Notomi T, Okayama H, Masubuchi H, Yonekawa T, Watanabe K, Amino N, Hase T. Loop-mediated isothermal amplification of DNA. Nucleic Acids Res. 2000; 28: E63.

4. Tomlinson J, B o on ham N. Potential of LAMP for detection of plant pathogens. CAB Reviews: Perspectives in Agriculture, Veterinary Science, Nutrition and Natural Resources 2008; 3: 1-7.

5. Mori Y, Nagamine K, Tomita N, Notomi T. Detection of loop-mediated isothermal amplification reaction by turbidity derived from magnesium pyrophosphate formation. Biochem Biophys Res Commun 2001; 289: $150-154$.

6. Tomita N, Mori Y, Kanda H, Notomi T. Loop-mediated isothermal amplification (LAMP) of gene sequences and simple visual detection of products. Nat Protoc. $2008 ; 3$ : 877-882.

7. Nagamine K, Hase T, Notomi T. Accelerated reaction by loop-mediated isothermal amplification using loop primers. Mol Cell Probes. 2002; 16: 223-229.

8. Kaczmarek J, Ję dryczka M. Characterization of two coexisting pathogen populations of Leptosphaeria spp., the cause of stem canker of brassicas. Acta Agrobot. 2011; 64 (2): 3-14.

9. Kaczmarek J, Jędryczka M, Cools H, Fitt BDL, Lucas JA, Latunde-Dada AO. Quantitative PCR analysis of abundance of airborne propagules of Leptosphaeria species in air samples from different regions of Poland. Aerobiologia. 2012; 28: 199-212.

10. Kaczmarek J, Jędryczka M, Fitt BDL, Lucas JA, Latunde-Dada AO. Analyses of air samples for ascospores of Leptosphaeria maculans and L. biglobosa with light microscopic and molecular techniques. J Appl Genet. 2009; 50: 411-419.

11. Mahuku GS, Hall R, Goodwin PH. Co-infection and induction of systemic acquired resistance by weakly and highly virulent isolates of Leptosphaeria maculans in oilseed rape. Physiol Mol Plant Pathol. 1996; 49: 61-72.

12. Kaneko H, Kawana T, Fukushima E, Suzutani T. Tolerance of loop-mediated isothermal amplification to a culture medium and biological substances. J Biochem Biophys Methods. 2007; 70: 499-501.

13. Moradi A, Nasiri J, Abdollahi H, Almasi M. Development and evaluation of a loop-mediated isothermal amplification assay for detection of Erwinia amylovora based on chromosomal DNA. Plant Pathol. 2012; 133: 609-620.

14. Dawidziuk A, Kasprzyk I, Kaczmarek J, Jędryczka M. Pseudothecial maturation and ascospore release of Leptosphaeria maculans and L. biglobosa in south-east Poland. Acta Agrobot. 2010; 63 (1): 107-120.

15. Stachowiak A, Olechnowicz J, Jędryczka M, Rouxel T, Balesdent MH, Happstadius I, Gladders P, Latunde-Dada A, Evans N. Frequency of avirulence alleles in field populations of Leptosphaeria maculans in Europe. Eur J Plant Pathol. 2006; 114: 67-75.

16. Hara-Kudo Y, Yoshino M, Kojima T, Ikedo M. Loop-mediated isothermal amplification for the rapid detection of Salmonella. FEMS Microbiol Lett. 2005; 253: $155-161$.

17. Imai M, Ninomiya A, Minekawa H, Notomi T, Ishizaki T, Tashiro M, Odagiri, T. Development of H5-RT-LAMP (loop mediated isothermal amplification) system for rapid diagnosis of $\mathrm{H} 5$ avian influenza virus infection. Vaccine 2006; 24: 6679-6682.

18. Hasiow-Jaroszewska B, Borodynko N. Detection of Pepino mosaic virus isolates from tomato by one-step reverse transcription loop-mediated isothermal amplification. Arch Virol. 2013; 158: 2153-2056.

19. Rostamkhani N, Haghnazari A, Tohidfar M, Moradi A. Rapid identification of transgenic cotton (Gossypium hirsutum L.) plants by loop-mediated isothermal amplification. Czech J Genet Plant Breed 2011; 47: 140-148.

20. Misawa Y, Yoshida A, Saito R, Yoshida H, Okuzumi K, Ito N. et al. Application of loop-mediated isothermal amplification technique to rapid and direct detection of methicillin-resistant Staphylococcus aureus (MRSA) in blood cultures. J Infect Chemother. 2007; 13: 134-140.

\section{Amplifikacja DNA w warunkach izotermicznych z wykorzystaniem starterów zapętlających (LAMP), jako dobre narzędzie do badań zmian w populacji Leptosphaeria w roślinach rzepaku i w próbach powietrza}

\section{Streszczenie}

Amplifikacja DNA w warunkach izotermicznych z wykorzystaniem starterów zapętlających (Loop Mediated Isothermal Amplification, LAMP) to innowacyjny, prosty, szybki, specyficzny i niedrogi sposób amplifikacji kwasów nukleinowych. Dzięki zastosowaniu specjalnego enzymu - polimerazy GspSSD, reakcja trwa krótko i można ją przeprowadzić w warunkach izotermicznych. Dzięki zastosowaniu 2-3 par starterów czułość i swoistość techniki jest znacznie wyższa, aniżeli w przypadku standardowych technik PCR. Technika LAMP jest uważana za użyteczne narzędzie do wykrywania i identyfikacji patogenów roślin. W niniejszej pracy przy pomocy LAMP badano skład populacji grzybów rodzaju Leptosphaeria, wywołujących groźną chorobę rzepaku, zwaną suchą zgnilizną kapustnych. Badania dotyczyły zarodników grzybów zawartych w próbach powietrza uzyskanych przy pomocy pułapki wolumetrycznej typu Hirsta, na Pomorzu w 2010 roku. Wyniki uzyskane przy pomocy techniki LAMP były bardzo zbliżone do uzyskanych przy zastosowaniu wysokoczułej metody Real-time PCR. Przeprowadzenie reakcji LAMP było znacznie łatwiejsze i mniej 
czaso- $\mathrm{i}$ kosztochłonne, ze względu na uproszczoną metodę izolacji DNA patogenów z tkanek roślinnych. Następnie metodę LAMP zastosowano do oceny składu populacji Leptosphaeria spp. w roślinach rzepaku z pól na Opolszczyźnie w 2013 roku. W przeciwieństwie do badań przeprowadzonych w latach 2002-2003, analiza objawów na liściach rzepaku wykazała wyższy udział gatunku L. maculans w porównaniu do L. biglobosa, co świadczy o zmianach w składzie populacji grzybów wywołujących suchą zgniliznę kapustnych na rzepaku w tej części Polski.

Handling Editor: Elżbieta Weryszko-Chmielewska

This is an Open Access digital version of the article distributed under the terms of the Creative Commons Attribution 3.0 License (creativecommons.org/licenses/by/3.0/), which permits redistribution, commercial and non-commercial, provided that the article is properly cited.

(CThe Author(s) 2013 Published by Polish Botanical Society 